\title{
Albimonas donghaensis gen. nov., sp. nov., a non- photosynthetic member of the class Alphaproteobacteria isolated from seawater
}

\author{
Correspondence \\ Chang-Jin Kim \\ changjin@kribb.re.kr
}

\author{
Jee-Min Lim, ${ }^{1} \dagger$ Che Ok Jeon, ${ }^{2} \dagger$ Ho Hee Jang, ${ }^{2}$ Dong-Jin Park, ${ }^{1}$ \\ Yong Kook Shin, ${ }^{3}$ Soo-Hwan $\mathrm{Yeo}^{4}$ and Chang-Jin Kim ${ }^{1}$ \\ ${ }^{1}$ Korea Research Institute of Bioscience and Biotechnology, 52 Oeundong, Yusong, \\ Daejeon 305-333, Republic of Korea \\ ${ }^{2}$ Division of Applied Life Science, EB-NCRC, PMBBRC, Gyeongsang National University, Jinju, \\ 660-701, Republic of Korea \\ ${ }^{3}$ Health Industry Center, Chungcheongbuk-Do 363-883, Republic of Korea \\ ${ }^{4}$ Rural Resources Development Institute of Agricultural Science and Technology, \\ Rural Development Administration, Suwon 411-853, Korea
}

\begin{abstract}
A moderately halophilic Gram-negative bacterium, strain $\mathrm{DS} 2^{\top}$, was isolated from seawater from the East Sea in Korea. Strain $D S 2^{\top}$ grew at salinities of $0-14 \%(w / v) ~ N a C l$ and at temperatures in the range $10-38{ }^{\circ} \mathrm{C}$. The cells were non-motile short rods $(1.0-1.4 \mu \mathrm{m}$ in width and 1.6-2.6 $\mu \mathrm{m}$ in length) and the major fatty acids were $\mathrm{C}_{18: 1} \omega 7 \mathrm{c}$ and 11-methyl $\mathrm{C}_{18: 1} \omega 7 \mathrm{c}$. The genomic DNA G +C content was 72.0 mol\% and the predominant lipoquinone was Q-10. The major cellular phospholipids were phosphatidylglycerol, diphosphatidylglycerol, phosphatidylethanolamine and phosphatidylcholine. Phylogenetic analyses based on 16S rRNA gene sequences showed that strain $\mathrm{DS} 2^{\top}$ formed a distinct phyletic line from the genus Rubrimonas within the Alphaproteobacteria. The levels of 16S rRNA gene sequence similarity with respect to the type strains of related genera were below $94 \%$. On the basis of physiological and phylogenetic properties, strain $D S 2^{\top}$ represents a novel genus and species of the Alphaproteobacteria, for which the name Albimonas donghaensis gen. nov., sp. nov. is proposed. The type strain is $\mathrm{DS}^{\top}$ (=KCTC $\left.12586^{\top}=\mathrm{DSM} 17890^{\top}\right)$.
\end{abstract}

Since Sato (1978) reported on aerobic methylotrophs containing bacteriochlorophyll $a$, a range of aerobic, anoxygenic, phototrophic bacteria have been described (Imhoff et al., 1984; Hiraishi \& Ueda, 1995; Suzuki et al., 1999, 2006; Albuquerque et al., 2002; Sorokin et al., 2005; Biebl et al., 2007). However, a non-pigmented microorganism, Albidovulum inexpectatum, which is closely related to the genera Rhodovulum, Thioclava and Rhodobacter but does not produce bacteriochlorophyll $a$, was isolated recently from a marine hot spring (Albuquerque et al., 2002). In this study, we also isolated (from seawater of the East Sea in Korea) a slightly halophilic non-pigmented bacterium that did not produce bacteriochlorophyll $a$. The isolate was not phototrophic but $16 \mathrm{~S}$ rRNA gene sequence analysis showed that it was

†These authors contributed equally to this work.

The GenBank/EMBL/DDBJ accession number for the 16S rRNA gene sequence of strain DS2 ${ }^{\top}$ is DO280370.

A transmission electron micrograph of cells of strain DS2 ${ }^{\top}$ is available as a supplementary figure with the online version of this paper. closely related to the genus Rubrimonas and analysis of phylogenetic and chemotaxonomic characteristics indicated that the isolate represented a new genus of the class Alphaproteobacteria.

Strain DS2 ${ }^{\mathrm{T}}$ was isolated from seawater from the East Sea in Korea by means of the serial dilution plating method, using incubation on marine agar 2216 (MA; Difco) at $28{ }^{\circ} \mathrm{C}$ for 3 days. Subcultivation was done on MA at $30{ }^{\circ} \mathrm{C}$ for 2-3 days. $\mathrm{NaCl}$ requirements and tolerance were determined in nutrient broth (Difco) supplemented with modified artificial seawater containing $\left(1^{-1}\right): 0-20 \%(\mathrm{w} / \mathrm{v})$ $\mathrm{NaCl}$ (increments of $1 \%$ ), $5.94 \mathrm{~g} \mathrm{MgSO}_{4} \cdot 7 \mathrm{H}_{2} \mathrm{O}, 4.53 \mathrm{~g}$ $\mathrm{MgCl}_{2} .6 \mathrm{H}_{2} \mathrm{O}, 0.64 \mathrm{~g} \mathrm{KCl}$ and $1.3 \mathrm{~g} \mathrm{CaCl}_{2}$. Growth was tested at different temperatures $\left(4-50{ }^{\circ} \mathrm{C}\right)$ and $\mathrm{pH}$ values (5.0-10.0) in marine broth (Gomori, 1955). Cell morphology and flagellation were investigated using light microscopy and transmission electron microscopy (JEM-1010; JEOL), as described previously (Jeon et al., 2005). Gram staining was determined using the bioMérieux Gram stain kit according to the manufacturer's instructions. Oxidase activity was tested using a Bactident oxidase strip (Merck) 
and catalase activity was determined by assessing bubble production in a $3 \%(\mathrm{v} / \mathrm{v})$ hydrogen peroxide solution. Nitrate reduction and the hydrolysis of aesculin, casein, gelatin, starch, Tween 80, L-tyrosine and urea were determined on MA according to the methods described by Cowan \& Steel (1965), Lanyi (1987) and Gerhardt et al. (1994). Acid production from D-galactose, D-glucose, Dlactose, L-arabinose, D-fructose, D-ribose, D-xylose and sucrose was determined as described by Leifson (1963). Growth under anaerobic conditions was determined after 5 days incubation on $\mathrm{MA}$ at $30^{\circ} \mathrm{C}$ in an anaerobic chamber. Strain $\mathrm{DS}^{\mathrm{T}}$ formed creamy, smooth, convex, glistening and circular/slightly irregular colonies on MA at $30{ }^{\circ} \mathrm{C}$ after 2 days incubation. The strain grew at $\mathrm{NaCl}$ concentrations in the range $0-14 \%(\mathrm{w} / \mathrm{v})$ and showed optimum growth at $2-5 \%(\mathrm{w} / \mathrm{v}) \mathrm{NaCl}$. Growth occurred from $\mathrm{pH} 6.0$ to $\mathrm{pH} 9.5$ (optimum, $\mathrm{pH}$ 7.0-8.0) in marine broth. Growth was observed at temperatures between 10 and $38{ }^{\circ} \mathrm{C}$, the optimum growth temperature being 28 $30{ }^{\circ} \mathrm{C}$. The cells of strain DS2 ${ }^{\mathrm{T}}$ were Gram-negative, strictly aerobic, non-motile rods $1.0-1.4 \mu \mathrm{m}$ in width and 1.6$2.6 \mu \mathrm{m}$ in length (see Supplementary Fig. S1, available in IJSEM Online). The strain showed oxidase- and catalasepositive reactions and did not reduce nitrate to nitrite. It hydrolysed gelatin and urea, but hydrolysis of aesculin, casein, L-tyrosine, starch and Tween 80 was not observed.

Whole-cell fatty acids of strain $\mathrm{DS}^{\mathrm{T}}$ were analysed according to the instructions of the Microbial Identification System (MIDI; Microbial ID) after cultivation on MA for 2 days at $30{ }^{\circ} \mathrm{C}$. The DNA G+C content (mol\%) was determined by reversed-phase HPLC using the method of Tamaoka \& Komagata (1984). Analyses of isoprenoid quinones and polar lipids were carried out using the methods described by Komagata \& Suzuki

Table 1. Cellular fatty acid compositions (\%) of strain DS2 ${ }^{\top}$ and the most closely related type strain

Strains: $1, \mathrm{DS}_{2}^{\mathrm{T}}$ (data from this study); 2, Rubrimonas cliftonensis OCh $317^{\mathrm{T}}$ (Suzuki et al., 2006). Data are expressed as percentages of total fatty acids. -, Not detected or not described.

\begin{tabular}{|lcc|}
\hline Fatty acid & $\mathbf{1}$ & $\mathbf{2}$ \\
\hline iso- $\mathrm{C}_{11: 0} 3-\mathrm{OH}$ & 0.89 & - \\
$\mathrm{C}_{16: 0}$ & 6.28 & 16 \\
$\mathrm{C}_{18: 0}$ & 7.69 & 2 \\
$\mathrm{C}_{16: 1}$ & - & 2 \\
$\mathrm{C}_{18: 1}$ & - & 69 \\
$\mathrm{C}_{18: 1} \omega 7 c$ & 53.48 & - \\
$11-$ methyl $\mathrm{C}_{18: 1} \omega 7 c$ & 21.19 & - \\
$\mathrm{C}_{14: 0} 3-\mathrm{OH}$ & - & 2 \\
$\mathrm{C}_{18: 0} 3-\mathrm{OH}$ & 4.02 & - \\
Unknown $_{\text {Summed feature } 2 *}^{*}$ & 3.28 & 8 \\
& 3.18 & - \\
\hline
\end{tabular}

${ }^{*}$ Summed feature 2 contains one or more of iso- $\mathrm{C}_{16: 1} \mathrm{I}$ and/or $\mathrm{C}_{14: 0}$ $3-\mathrm{OH}$.
(1987). The major cellular fatty acids of strain $\mathrm{DS}^{\mathrm{T}}$ (on MA) were $\mathrm{C}_{18: 1} \omega 7 c$ (53.48\%), 11-methyl $\mathrm{C}_{18: 1} \omega 7 c$ $(21.19 \%), \mathrm{C}_{18: 0}(7.69 \%)$ and $\mathrm{C}_{16: 0}(6.28 \%)$ (Table 1), being different from those of the genus Rubrimonas (which is, at the time of writing, the most closely related genus). Strain DS2 ${ }^{\mathrm{T}}$ was found to have high levels of the fatty acids $\mathrm{C}_{18: 1} \omega 7 c(53.48 \%)$ and 11-methyl $\mathrm{C}_{18: 1} \omega 7 c(21.19 \%)$, whereas these fatty acid components were not detected, even in trace amounts, in the cell membrane of Rubrimonas cliftonensis OCh $317^{\mathrm{T}}$ (Table 1). The genomic DNA G $+\mathrm{C}$ content of strain $\mathrm{DS}^{\mathrm{T}}$ was $72.0 \mathrm{~mol} \%$ and the predominant isoprenoid quinone was Q-10. The strain contained phosphatidylglycerol, diphosphatidylglycerol, phosphatidylethanolamine and phosphatidylcholine as the major polar lipids. The typical phenotypic and chemotaxonomic properties of strain DS2 ${ }^{\mathrm{T}}$ are compared with those of the closest phylogenetic relative, Rubrimonas cliftonensis, in Table 2, many of which allow the differentiation of strain $\mathrm{DS}^{\mathrm{T}}$ from the genus Rubrimonas.

The $16 \mathrm{~S}$ rRNA gene of strain DS2 ${ }^{\mathrm{T}}$ was amplified using PCR with primers Eubac 27F and 1492R (Lane, 1991) and then sequenced. The resultant $16 \mathrm{~S}$ rRNA gene sequence (1383 nt) was compared with 16S rRNA gene sequences available from GenBank, using the BLAST program (http:// www.ncbi.nlm.nih.gov/BLAST/) to determine an approximate phylogenetic affiliation, and gene sequences were

Table 2. Differential phenotypic characteristics of strain $D S 2^{\top}$ and the most closely related species

Taxa: 1, strain DS2 ${ }^{\mathrm{T}}$ (data from this study); 2, Rubrimonas cliftonensis (Suzuki et al., 1999). +, Positive; -, negative; w, weakly positive. Both are positive for oxidase and catalase activities, for hydrolysis of urea and for acid production from L-arabinose and D-xylose. Both are negative for anaerobic growth, in the ONPG reaction, for hydrolysis of Tween 80 and starch and for acid production from D-lactose and sucrose.

\begin{tabular}{|lcc|}
\hline Characteristic & $\mathbf{1}$ & $\mathbf{2}$ \\
\hline Cell morphology & Short rod & Short rod \\
Size $(\mu \mathrm{m})$ & $1.0-1.4$ & $1.0-1.5$ \\
& $\times 1.6-2.6$ & $\times 1.2-2.0$ \\
Flagellation & - & Polar flagella \\
Motility & - & + \\
NaCl range $(\%$, w/v) & $0-14$ & $0.5-7.5$ \\
Optimum pH range & $7.0-8.0$ & $7.5-8.0$ \\
Optimum growth temperature $\left({ }^{\circ} \mathrm{C}\right)$ & $28-30$ & $27-30$ \\
Nitrate reduction & - & $\mathrm{w}$ \\
Indole production & - & + \\
Hydrolysis of gelatin & $\mathrm{w}$ & - \\
Acid production from: & & \\
$\quad$ D-Fructose & - & + \\
D-Galactose & - & + \\
D-Glucose & - & + \\
D-Ribose & - & + \\
DNA G+C content $(\mathrm{mol} \%)$ & 72.0 & $74.0-74.8$ \\
\hline
\end{tabular}


aligned with those of closely related species using CLUSTAL W software (Thompson et al., 1994). Phylogenetic trees were constructed using three different methods, i.e. the neighbour-joining, maximum-likelihood and maximumparsimony algorithms available in PHYLIP, version 3.6 (Felsenstein, 2002). Using the FASTA3 program in EBI Tools (http://www.ebi.ac.uk/fasta33/), 16S rRNA gene sequence comparisons for similarity calculations were made between strain $\mathrm{DS}^{\mathrm{T}}$ and related organisms. A bootstrap analysis was performed according to the algorithm of the Kimura two-parameter model (Kimura, 1980) of the neighbour-joining method in the PHYLIP package. Phylogenetic analysis based on 16S rRNA gene sequences showed that strain $\mathrm{DS}^{\mathrm{T}}$ formed a distinct phylogenetic lineage with respect to the most closely related genus, Rubrimonas (class Alphaproteobacteria), with $69 \%$ bootstrap support (Fig. 1). The topologies of the phylogenetic trees built using the maximum-likelihood and maximum-parsimony algorithms also supported the notion that the isolate could represent a phylogenetic genus that was distinct from the most closely related genera (data not shown). A comparative analysis of $16 \mathrm{~S}$ rRNA gene sequences showed that the levels of sequence similarity between strain $\mathrm{DS}^{\mathrm{T}}$ and the type strains of related genera were below $94 \%$. On the basis of physiological and molecular data, strain $\mathrm{DS}^{\mathrm{T}}$ represents a novel genus and species within the class Alphaproteobacteria, for which the name Albimonas donghaensis gen. nov., sp. nov. is proposed.

\section{Description of Albimonas gen. nov.}

Albimonas (Al.bi.mo'nas. L. adj. albus white; Gr. fem. n. monas monad, unit; N.L. fem. n. Albimonas white monad).

Colonies are not pigmented. Nitrate is not reduced to nitrite. Cells are non-motile, non-spore-forming, short rods. Catalase- and oxidase-positive. Bacteriochlorophyll $a$ is not synthesized under aerobic conditions. Major fatty acids are $\mathrm{C}_{18: 1} \omega 7 c$ and 11-methyl $\mathrm{C}_{18: 1} \omega 7 c$. Major isoprenoid quinone is Q-10. Predominant polar lipids are phosphatidylglycerol, diphosphatidylglycerol, phosphatidylethanolamine and phosphatidylcholine. The type species is Albimonas donghaensis.

\section{Description of Albimonas donghaensis sp. nov.}

Albimonas donghaensis (dong.ha.en'sis. N.L. fem. adj. donghaensis belonging to Donghae, where the organism was isolated).

Colonies are smooth, glistening, circular and slightly irregular and cream in colour. Cells are strictly aerobic, Gram-negative and approximately $1.0-1.4 \mu \mathrm{m}$ wide and $1.6-2.6 \mu \mathrm{m}$ long. Growth occurs between 10 and $38{ }^{\circ} \mathrm{C}$ (optimally at $28-30{ }^{\circ} \mathrm{C}$ ) and from $\mathrm{pH} 6.0$ to $\mathrm{pH} 9.5$ (optimally at $\mathrm{pH} 7.0-8.0$ ). Cells grow at salinities of 0 $14 \%(\mathrm{w} / \mathrm{v}) \mathrm{NaCl}$ (optimally at 2-5\%,w/v). Gelatin and urea are hydrolysed, but hydrolysis of aesculin, casein, starch, L-tyrosine and Tween 80 is not observed. Acid is produced from L-arabinose and D-xylose, but not from Dgalactose, D-glucose, D-fructose, lactose, D-ribose or sucrose. Negative for indole and $\mathrm{H}_{2} \mathrm{~S}$ production and in the ONPG reaction. Voges-Proskauer test is positive (weak). Alkaline phosphatase, esterase (C4), esterase lipase (C8), leucine arylamidase and acid phosphatase are produced, but lipase (C14), valine arylamidase, cystine arylamidase, trypsin, $\alpha$-chymotrypsin, $\alpha$-galactosidase, $\beta$ galactosidase, $\beta$-glucuronidase, $\alpha$-glucosidase, $\beta$-glucosidase, $N$-acetyl- $\beta$-glucosaminidase, $\alpha$-mannosidase and $\alpha$ fucosidase are not produced. Naphthol-AS-BI-phosphohydrolase activity is weak. The $\mathrm{G}+\mathrm{C}$ content of the genomic DNA of the type strain is $72.0 \mathrm{~mol} \%$ (HPLC).

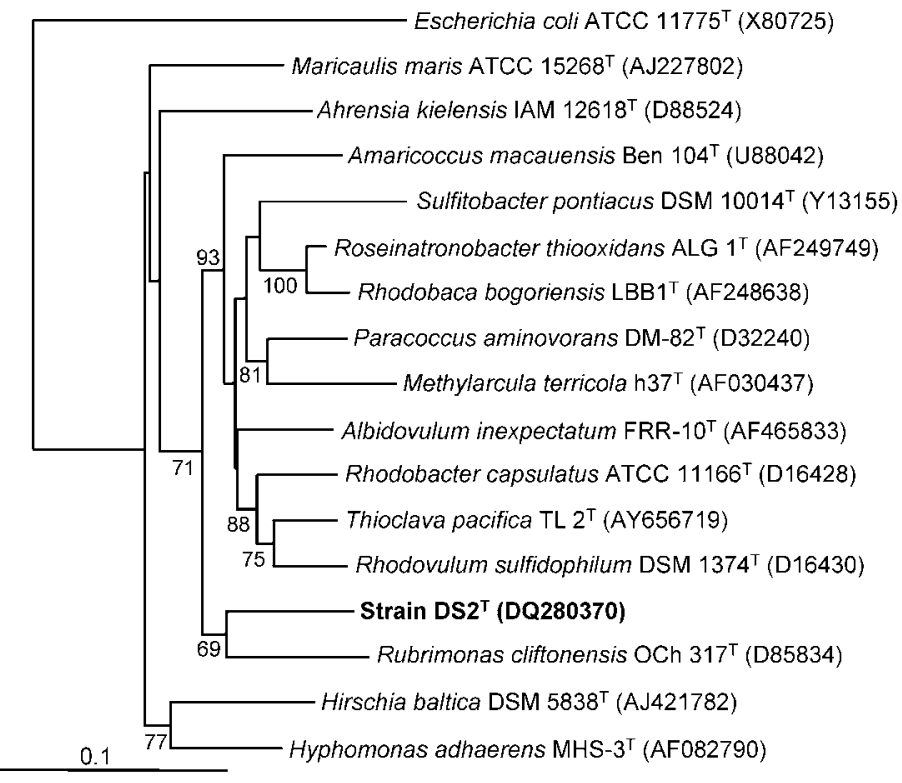

Fig. 1. Neighbour-joining phylogenetic tree, based on 16S rRNA gene sequences, showing the positions of strain $\mathrm{DS}^{\top}$ and some related taxa. Bootstrap percentages (based on 1000 replicates) greater than $50 \%$ are shown at branch points. Bar, 0.1 substitutions per nucleotide position. 
The type strain, DS2 ${ }^{\mathrm{T}}\left(=\right.$ KCTC $\left.12586^{\mathrm{T}}=\mathrm{DSM} 17890^{\mathrm{T}}\right)$, was isolated from seawater from the East Sea in Korea.

\section{Acknowledgements}

This work was supported by the 21C Frontier Microbial Genomics and Application Center Program, Ministry of Science and Technology (Republic of Korea) and by the Korea Foundation for International Cooperation of Science and Technology (KICOS) through a grant provided by the Korean Ministry of Science and Technology in the Global Partnership Program (no. M60602000001-06E0200-00100).

\section{References}

Albuquerque, L., Santos, J., Travassos, P., Nobre, M. F., Rainey, F. A., Wait, R., Empadinhas, N., Silva, M. T. \& da Costa, M. S. (2002). Albidovulum inexpectatum gen. nov., sp. nov., a nonphotosynthetic and slightly thermophilic bacterium from a marine hot spring that is very closely related to members of the photosynthetic genus Rhodovulum. Appl Environ Microbiol 68, 4266-4273.

Biebl, H., Pukall, R., Lünsdorf, H., Schulz, S., Allgaier, M., Tindall, B. J. \& Wagner-Döbler, I. (2007). Description of Labrenzia alexandrii gen. nov., sp. nov., a novel alphaproteobacterium containing bacteriochlorophyll $a$, and a proposal for reclassification of Stappia aggregata as Labrenzia aggregata comb. nov., of Stappia marina as Labrenzia marina comb. nov. and of Stappia alba as Labrenzia alba comb. nov., and emended descriptions of the genera Pannonibacter, Stappia and Roseibium, and of the species Roseibium denhamense and Roseibium. Int J Syst Evol Microbiol 57, 1095-1107.

Cowan, S. T. \& Steel, K. J. (1965). Manual for the Identification of Medical Bacteria. London: Cambridge University Press.

Felsenstein, J. (2002). PHYLIP (phylogeny inference package), version 3.6a. Distributed by author. Department of Genome Sciences, University of Washington, Seattle, USA.

Gerhardt, P., Murray, R. G. E., Wood, W. A. \& Krieg, N. R. (editors) (1994). Methods for General and Molecular Bacteriology. Washington, DC: American Society for Microbiology.

Gomori, G. (1955). Preparation of buffers for use in enzyme studies. Methods Enzymol 1, 138-146.

Hiraishi, A. \& Ueda, Y. (1995). Isolation and characterization of Rhodovulum strictum sp. nov. and some other purple nonsulfur bacteria from colored blooms in tidal and seawater pools. Int J Syst Bacteriol 45, 319-326.
Imhoff, J. F., Trüper, H. G. \& Pfennig, N. (1984). Rearrangement of the species and genera of the phototrophic "purple nonsulfur bacteria". Int J Syst Bacteriol 34, 340-343.

Jeon, C. O., Lim, J.-M., Lee, J. M., Xu, L. H., Jiang, C. L. \& Kim, C.-J. (2005). Reclassification of Bacillus haloalkaliphilus Fritze 1996 as Alkalibacillus haloalkaliphilus gen. nov., comb. nov. and the description of Alkalibacillus salilacus sp. nov., a novel halophilic bacterium isolated from a salt lake in China. Int J Syst Evol Microbiol 55, 1891-1896.

Kimura, M. (1980). A simple method for estimating evolutionary rates of base substitutions through comparative studies of nucleotide sequences. J Mol Evol 16, 111-120.

Komagata, K. \& Suzuki, K. (1987). Lipid and cell-wall analysis in bacterial systematics. Methods Microbiol 19, 161-207.

Lane, D. J. (1991). 16S/23S rRNA sequencing. In Nucleic Acid Techniques in Bacterial Systematics, pp. 115-175. Edited by E. Stackebrandt \& M. Goodfellow. Chichester: Wiley.

Lanyi, B. (1987). Classical and rapid identification methods for medically important bacteria. Methods Microbiol 19, 1-67.

Leifson, E. (1963). Determination of carbohydrate metabolism of marine bacteria. J Bacteriol 85, 1183-1184.

Sato, K. (1978). Bacteriochlorophyll formation by facultative methylotrophs, Protaminobacter ruber and Pseudomonas AM 1. FEBS Lett 85, 207-210.

Sorokin, D. Yu., Tourova, T. P., Spiridonova, E. M., Rainey, F. A. \& Muyzer, G. (2005). Thioclava pacifica gen. nov., sp. nov., a novel facultatively autotrophic, marine, sulfur-oxidizing bacterium from a near-shore sulfidic hydrothermal area. Int J Syst Evol Microbiol 55, 1069-1075.

Suzuki, T., Muroga, Y., Takahama, M., Shiba, T. \& Nishimura, Y. (1999). Rubrimonas cliftonensis gen. nov., sp. nov., an aerobic bacteriochlorophyll-containing bacterium isolated from a saline lake. Int J Syst Bacteriol 49, 201-205.

Suzuki, T., Mori, Y. \& Nishimura, Y. (2006). Roseibacterium elongatum gen. nov., sp. nov., an aerobic, bacteriochlorophyll-containing bacterium isolated from the west coast of Australia. Int J Syst Evol Microbiol 56, 417-421.

Tamaoka, J. \& Komagata, K. (1984). Determination of DNA base composition by reversed-phase high-performance liquid chromatography. FEMS Microbiol Lett 25, 125-128.

Thompson, J. D., Higgins, D. G. \& Gibson, T. J. (1994). CLUSTAL W: improving the sensitivity of progressive multiple sequence alignment through sequence weighting, position-specific gap penalties and weight matrix choice. Nucleic Acids Res 22, 4673-4680. 